\title{
BENEFITING MORE OF PROJECT WORK IN A LARGE CLASS
}

\author{
Rohaniatul Makniyah \\ MAN 1 Kota Tangerang, Banten Indonesia \\ Email:ms.ani.rohani@gmail.com
}

\begin{abstract}
This classroom action research aims at finding an alternative of how to implement $P j B L$ for the purpose of taking more benefits of project works and analyzing the relevance of the implementation of which within an EFL secondary school large class. The subject of the study are 41 learners of grade XI MAN 1 Kota Tangerang. They are assigned to work in groups with a set of meaningful processes to do in every project work given within a period of time. The study found that project works can be maximized on the grounds that: (1) projects should be based on realistic and challenging tasks; (2) project should be structured within a set of meaningful processes; (3) project works are to be conducted collaboratively in groups to facilitate learners to learn in a large class.
\end{abstract}

Keywords: challenging and realistic tasks, EFL, large class, PjBL, structured and meaningful processes

\begin{abstract}
Penelitian tindakan kelas ini bertujuan untuk menemukan alternatif menerapkan PjBL lebih efektif dalam relevansi penggunaannya di kelas besar EFL seklah menengah. Penelitian tindakan kelas diikuti 41 peserta didik kelas XI MAN 1 Kota Tangerang banten. Peserta didik ditugaskan untuk bekerja dalam kelompok dengan serangkaian proses yang berarti dalam bentuk proyek yang diberikan dalam jangka waktu tertentu. Penelitian tersebut tersebut menemukan bahwa pekerjaan proyek dapat dimaksimalkan dengan alasan bahwa: (1) proyek harus didasarkan pada tugas-tugas yang realistis dan menantang; (2) proyek harus terstruktur dalam serangkaian proses yang berarti; (3) pekerjaan proyek dilakukan secara kolaboratif dalam kelompok untuk memfasilitasi peserta didik untuk belajar di kelas yang besar.
\end{abstract}

Kata Kunci: EFL, kelas besar, PJbL, proses belajar tersetruktur dan bermakna, tugas menantang dan realistic 


\section{INTRODUCTION}

Project-Based Learning (PjBL) isnot something new to many educators across nation. Many schools havealready implemented it in their teaching and learning processes. However, empirical study shows that its implementation is very much depending on every individual

teacher's point of view about what PBL is. Some teachers may conduct one single session, give an assignment without guiding the students during the processes and consider it as a project.

Others may give a set of tasks which involves some sets of processes and provide some guidance on what is expected of the project in a certain period of time, sometimes even the whole teaching unit, and then considers it as a project. The previous refers to as"underexploited" project work; as for the latter, students benefits more of project works since they are involved in "information gathering, processing and reporting" thus making them engage in meaningful learning processes which, the end, increases their knowledge about the content and the language (Alan \& Stoller, 2005).

One of PjBL model was formulated by Alan and Stoller (2005: p. 11). He points out that: "Projects that are structured to maximize language, content, and real-life skill learning require a combination of teacher guidance, teacher feedback, student engagement, and elaborated tasks with some degree of challenge. Generally, such projects are multidimensional". Clearly there are some points in demand when implementing PBL so it can maximize "language", "content" and "real-life skills" gain on the part of the students. The key words are "structure", "guidance," "feedback," and "challenge." This means that teachers should provide a structure to the project beforehand, give feedback on the projects during the processes, and make students in such a way engage in the given challenging project. That is why the tasks given should be realistic, elaborated and challenging to the students.

MAN 1 Kota Tangerang is among the $16 \%$ of 26.000 public senior high schools in Indonesia under the Ministry of Religious Affairs. Currently, it caters about 744 students with the everage of 40 to 45 students in each class. Almost similar situation can be found in Thailand and China. Thailand secondary public schools have around 45 to 55 students on average in each class (Hayes, 1997), and in China, it is very common to see teachers teaching more than 50 students in public primary or secondary schools there (Wang \& Zhang, Teaching Large Classes in China-English as a Foreign Language-Notes, April 2011). These classroom settings are, no doubt, large classes because the ideal 
language class is 30 (Hayes, 1997); with this number, students can still communicate with one another, as communication is of high importance in a language class. However, Indonesia is one of the developing countries with a growing population; this means that there are more and more students coming to public schools, making having large classes in public schools is unavoidable, if not obligatory.

This study applies Alan and Stoller's (2005) steps to do project work with a little modification, focuses on how to implement the latter $\mathrm{PjBL}$ in an EFL large classroom setting in MAN 1 Kota Tangerang. The question is then: What are some possible steps so the students can benefit more on the target language as well as content gain? How can students benefit more of project works in a large EFL class in MAN 1 Kota Tangerang?

\section{METHODOLOGY}

This is a two cycles classroom action research which took place in MAN 1 Kota Tangerang. The participants are 41 students of grade XI science 2 . Their ages ranged between 15 to 16 years old. There are 24 girl and 13 boy students in this class. Field notes and photograph-taking were applied to gather the data. The students are observed while doing the sets of activities for the purpose of accomplishing a given project. Questionnaires were also given at the end of the project to find out students' feeling and perceptions towards the implementation of PBL in their class.

The research was conducted at MAN 1 Tangerang City Banten in 2015 using Kemmis- McTaggart CAR Model to implement the best way of Alan and Stoller BjBL model. The cycle of CAR was formulated in Figure 1.

Alan and Stoller (2005:12-13) propose an alternative step on how to deliver project work in EFL settings, they are as follows:

1. Step 1: Students and instructor agree on a theme for the project.

2. Step 2: Students and instructor determine the final outcome of theproject.

3. Step 3: Students and instructorstructure the project.

4. Step 4: Instructor prepares studentsfor the demands of information gathering.

5. Step 5: Students gather information.

6. Step 6: Instructor prepares studentsto compile and analyze data.

7. Step 7: Students compile and analyzeinformation.

8. Step 8: Instructor prepares studentsfor the language demands of the final activity. 
9. Step 9: Students present the finalproduct.

10. Step 10: Students evaluate theproject.

\section{FINDING AND DISCUSSION Project 1}

The lead-in stage begins by showing pictures of a girl writing letter and someone writing a salutation to the whole class; this is one of the effective ways of leading-in students to the lesson, thus conducive atmosphere iscreated as well as teacher guiding and exploring students' knowledge and ability of the upcoming lesson. As such the motivation needed to make the lesson more meaningful to the students was achieved. The next step was conveying learning objectives of the lesson which definitely needs to be done in order to let the students know where they are heading, what they are facing and what is expected of them.

The two questions which signal the beginning stage of this particular projectbased learning are based on the students' real-life activities which are:

(1) the students being able to produce a personal letter sharing about their life experiences and values for the purpose of strengthening the family/relative relationship, and friendship; (2) the students being able to upload the letter in their classroom blog indicating the needs on the part of the students to be able to not only aware of the information technology but are able to apply it for their real life necessities. As we can see the two questions are very authentic as they reflect the students' real life. The whole teaching and learning process provide a meaningful experience for the students to strengthen the relationship among family and friends and apply Information Technology in their daily life Galanek, J. D., Gierdowski, D. C., \& Brooks, D. C. (2018). Aside from that, the title of the project which is "Blogging for Silaturahim Bonding" also provides the real Islamic way of keeping close relationship with everyone around them.

Exposing the students with video from you tube presents vivid explanation about the way how to make personal letter as it is presented not only in the form of oral explanation but also in an audio-visual version of the lesson. This process also provides the students with an exposure to English environment, which is very important for their learning process. Getting exposure will surely benefit the students with a contextual input. "One of the most important tasks of the teacher is to give learners enough exposure to examples of language in different contexts, and from different speakers and can also use natural input from cassettes, television, video, web sites, magazines, and books" (Teaching English). As we can see, aside from the teacher, video can also provide natural input as a useful example of how the language is used in the right context.

Students are assigned to analyze the social function; the language components and the text 
structure from a given personal letter providing useful exploration stage for the students to dig in into the lesson learnt on their own. The activity of finding out how to post their letter in a blog also provides a useful exploration practice for the students about one of real-life skills needed in this era.

Posting their own writing in a blog and having their own classroom blog isthe first experience for the students, thus for this particular class this is an innovation. In fact, this is an innovation for other classes too on the grounds that such technique has not been applied in the rest of the classes. This is the pilot project for the implementation of the classroom blog to boost students' writing skills. In addition, the implementation of the classroom blog gives the students excitements, which is good for the accomplishment of the project.

Table 1 presents the result of the questionnaires. The table clearly displays that most of the students

\begin{tabular}{|l|l|c|c|c|c|c|}
\hline NO & \multicolumn{1}{|c|}{ QUESTIONS } & $\mathbf{1}$ & $\mathbf{2}$ & $\mathbf{3}$ & $\mathbf{4}$ & $\mathbf{5}$ \\
\hline $\mathbf{1 .}$ & $\begin{array}{l}\text { I can tell the } \\
\text { difference } \\
\text { between formal } \\
\text { and } \\
\text { informal/persona } \\
\begin{array}{l}\text { l } \\
\text { letter. }\end{array}\end{array}$ & 10 & 18 & 8 & 1 & 0 \\
\hline 2. & $\begin{array}{l}\text { I find some } \\
\text { information/read } \\
\text { /ask } \\
\text { someone/teacher }\end{array}$ & 15 & 17 & 5 & 1 & 0 \\
\hline
\end{tabular}

responded either DEFINITELY or YES for all the questions, few of the students responded MAY BE and only four students responded either NO or NOT AT ALL. Furthermore, zero students stated that they do not like the project. This signals positivity on the part of the students toward the whole pilot projectthe implementation of the classroom blog delivered through project-based learning. However the whole teaching and learning process still put four students at a disadvantage as one of them still cannot tell the difference between formal and informal letter, and one students state that he/she did not find any information about how to write a personal letter, and still one student stated that he/she do not know how to write a personal letter and how to post it on the blog. This definitely needs further actions. It could possibly be that their digging in the information in the group is not quite effective Silalahi, T. F., \& Hutauruk, A. F. (2020). That is why feedbacks were given to them to clear everything up. The giving feedback is a very important step at this point. 


\begin{tabular}{|l|l|l|l|l|l|l|}
\hline \multicolumn{7}{|l|}{$\begin{array}{l}\text { about how to write a } \\
\text { personal letter. }\end{array}$} \\
\hline 3. & $\begin{array}{l}\text { I know how to } \\
\text { write a } \\
\text { personal letter. }\end{array}$ & 13 & 16 & 7 & 1 & 0 \\
\hline 4. & $\begin{array}{l}\text { I know how to } \\
\text { post } \\
\text { my letter in a blog. }\end{array}$ & 10 & 17 & 9 & 0 & 1 \\
\hline 5. & $\begin{array}{l}\text { I like the } \\
\text { project. } \\
\text { (Blogging for } \\
\text { "Silaturahim } \\
\text { " } \\
\text { Bonding) }\end{array}$ & 10 & 26 & 1 & 0 & 0 \\
\hline
\end{tabular}

The questionnaires also provide useful information about the students' feeling and the reasons why they like project-based learning. They said that they like project- based learning because they can make friends, share information to each other, become creative, broaden their imagination, bond the relationship with one another and augment their knowledge. When clarified what they meant by 'add friends' is that they wish to have a friend from other country because when they go blogging, their writing would possibly be read by people from other countries. The questionnaires also reveal the reasons of students not liking the project; the reasons are, among others, the technical problem, in this case the internet connection which is not available in their classroom. That is why many students upload their work in the teachers' room using the teacher's and the colleague's lap top computer. In addition, some of the student's state that projectbased learning make their activity become hectic. When asked whether hectic make them do not want to have another project, they said "no", they want to have another project. Furthermore, there is one very interesting statement "there is no reason for me for didn't like the project;" the statement is absolutely relieving. This particular student absolutely likes the project.

\section{Project 2}

As stated on part B that working together can also be a problem for some students. Bayu, and Rachma seems to enjoy working alone rather than working with the group. Bayu is actually one of the students with low capability in English subject. That's heterogeneous grouping was applied based on their capabilities. Bayu was grouped with Ratna who is actually one of the bright students in English subject. However, the expected outcome that Ratna would help Bayu in his journey to solve some problems failed. Finding out the reason why, Marzano, et.al said that effective learning in groups must have at least the following elements (J, J, \& E, 2001) (Marzano, et. al, pages 85-86):

- They must include every member of the group.

- $\quad$ Each person has a valid job to perform with a known standard of completion.

- Each member is invested in completing the task or learning goal.

- Each member is accountable individually and collectively.

So it turned out that the 
explanations on task division for each member was not quite clear for Bayu and Ratna; thus should be made clear to them for the second time. Power point presentation was applied to present the lesson. The students not only listen to the objectives, the problems, the questions, the sample of formal invitation, the expected end product, the scoring system, and the peer assessment but also see and read with their own eyes the sentences on the power point presentation. These teaching activities certainly facilitate the inactive as well as the active students who most probably having auditory and visual learning styles as they were "forced" to tune in into the lesson. Colourful pictures were displayedat the lead-in stage. This also has been proven to be very useful to tap and activate the students' knowledge on the upcoming lesson. The famous saying that: "pictures speak a thousand words" is true here as they not only provide vivid explanations about the lesson, they also draw the students' attention into the lesson. The showing pictures to the students is of the utmost importance as the English lesson in this particular class is on 10 and 11 slot, the last slot of the day. The pictures provide extrinsic motivation to the inactive as well as the active students as they actually gave their attention to lesson at the very beginning stage of the lesson. Aside from that, you tube video was given displaying some examples of wall bulletin, the end product expected of the project. This video also provide proof of the efforts to get the inactive students to get into the lesson, and it is true because the students turn to be inacti during the video show but during the discussion. This indicates that: despite their being not quite active during the discussion stage, the most important message of today's lesson, what is expected of them, was witnessed by all students even the inactive ones.

Perfect preparation leads to perfect teaching and learning process; like the famous saying: "if you fail to prepare you prepare to fail" is true. The lesson started by building a conducive atmosphere, conveying the lesson objectives, showing some interesting suitable pictures to tap and activate students' knowledge on the upcoming lesson at the beginning stage. Power point presentation was applied during the core stage to explain the lesson. A you tube video was also given to expose students with what is expected of them, as the end result of the lesson. The wall bulletin presented on picture $8,9,10$, and 11 absolutely provide prove of the benefit of the video showing. They can come up with interesting, colorful, informative wall bulletin with their own creativities the following week.

Another thing revealed from the 
research is that clear tasks division facilitate cooperation among students. The picture below shows cooperation among the students in the group. Thus students-student's interactions are clearly facilitated towards finishing the task and producing the desired product the group wish to achieve. Still another thing is that worksheet provides individual tasks, as such students must cooperate with one another to finish the whole tasks. In other words, each individual student has his/her own task to finish. That each task makes up whole group tasks. So, each student in one group should contribute to the group's success. Individual success brings group's success.

\section{CONCLUSION}

All in all, this study found that project works can be maximized even ina large EFL class. To achieve this, there are at least three requirements to be fulfilled. The first and foremost is projects should of grade XI science 2 for making the research possible. be based on realistic and challenging tasks. The second important requirement is that project should be structured within sets of meaningful processes and guidance and feedback should also be given during the processes. The last but not least is that project works are to be conducted collaboratively in groups to facilitate learners to learn in a large EFL class. It is suggested that PBL is implemented in six phases. Thus, no need to hesitate if English public-school teachers wish to apply PBL in their large classrooms settings as learning outcome can actually be maximized.

\section{ACNOWLEDGEMENT}

The writer would like to convey her deepest gratitude to Dr. Asip Suryadi, M. Ed for his guidance of the research. The writer also would like to express her gratitude to the Headmaster of MAN 1 Kota Tangerang and students 


\section{DAFTAR PUSTAKA}

Alan, B., \& Stoller, F. L. (2005).

Maximizing teh Benefit of Project

Work in Foreign Language

Classroom. English Teaching Forum, 10-18.

Hayes, D. (1997). Helping Teachers to Cope with Large Classes. ELT Journal , 106-116.

Marzano., R.J, Pickering . D. J., \& Pollock., J. E. (2001). Classroom Instruction that Works: Reasearchbased Strategies for Increasing Students' Achievement. In VA: Association for Supervision and Curriculum Development.

Alexandria. Teaching English. (n.d.). Retrieved April Saturday , 2016, from British Council Website: https://www.teachingenglish.o rg.uk/article/exposure

Wang, Q., \& Zhang, N. (2011, April). Teaching Large Classes in China -English as a Foreign Language (Notes, April 2011). Beijing, China.

Radianti, J., Majchrzak, T. A., Fromm, J., \& Wohlgenannt, I. (2020). A systematic review of immersive virtual reality applications for higher education: Design elements, lessons learned, and research agenda. Computers \& Education, 147, 103778

Shim, T. E., \& Lee, S. Y. (2020). College students' experience of emergency remote teaching due to COVID19. Children and youth services review, 119, 105578.
Jäggle, G., Merdan, M., Koppensteiner, G., Brein, C., Wallisch, B., Marakovits, P., ... \& Vincze, M. (2019, April). Project-based learning focused on cross-generational challenges. In International Conference on Robotics in Education (RiE) (pp. 145-155). Springer, Cham.

Galanek, J. D., Gierdowski, D. C., \& Brooks, D. C. (2018). ECAR study of undergraduate students and information technology (Vol. 12, p. 12). 2018.

Silalahi, T. F., \& Hutauruk, A. F. (2020). The Application of Cooperative Learning Model during Online Learning in the Pandemic Period. Budapest International Research and Critics Institute-Journal (BIRCI-Journal), 3(3). 